\title{
Phytophthora Resistance Through Production of a Fungal Protein Elicitor ( $\beta$-Cryptogein) in Tobacco
}

\author{
David Tepfer, ${ }^{1}$ Catherine Boutteaux, ${ }^{1}$ Catherine Vigon, ${ }^{1}$ Sylvie Aymes, ${ }^{2}$ Valérie Perez, ${ }^{2}$ Michael J. \\ O'Donohue, ${ }^{2}$ Jean-Claude Huet, ${ }^{2}$ and Jean-Claude Pernollet ${ }^{2}$ \\ ${ }^{1}$ Biologie de la Rhizosphère, INRA, Route de St Cyr, F-78026 Versailles Cedex, France; ${ }^{2}$ Biochimie et \\ Structure des Protéines, INRA, Domaine de Vilvert, F-78352 Jouy-en-Josas Cedex, France \\ Accepted 26 September 1997.
}

Transformation of tobacco with a gene encoding the fungal elicitor protein, $\beta$-cryptogein, resulted in resistance to the pathogen Phytophthora parasitica var. nicotianae. Resistance was improved when the foreign gene was in the hemizygous state, and a single amino acid substitution that reduced the necrotic effects of the protein also conferred some resistance.

Plants resist disease through a battery of defenses, including differential growth, cell death and the production of phytoalexins, pathogen wall-degrading enzymes, and ribosomeinactivating proteins. In tobacco, certain Phytophthora spp. induce generalized defense responses accompanied by only limited tissue decomposition. This reaction is mimicked by a culture filtrate (Csinos et al. 1977, 1978). In the case of Phytophthora cryptogea, the active principle is a small, basic protein (98 amino acids; $\mathrm{pI}=9.8$ ), called $\beta$-cryptogein, which is abundantly secreted into the culture medium (Ricci et al. 1989; Nespoulous et al. 1992; Kamoun et al. 1993; Pernollet et al. 1993; O’Donohue et al. 1995). Similar proteins from other Phytophthora spp., termed elicitins, vary in sequence and in their ability to induce necrosis and trigger defense responses, with the $\beta$ (basic) subfamily producing more necrosis than the $\alpha$ (acidic) subfamily (Nespoulous et al. 1992; Pernollet et al. 1993). Expression in Escherichia coli of a synthetic gene encoding $\beta$-cryptogein produced a protein having the predicted necrotic activity when infiltrated into tobacco leaves, and a single amino acid substitution (valine for lysine in position 13) decreased this necrotic effect, giving a $\beta$ elicitin the properties of an $\alpha$-elicitin (O'Donohue et al. 1995). Although the tertiary structure of $\beta$-cryptogein has been determined (Boissy et al. 1996), and its necrotic and defenseinducing sites identified (Perez et al. 1997), little is known about its molecular functions.

Phytophthora parasitica var. nicotianae is thought to be virulent in tobacco because it produces no known elicitin; thus, the host fails to perceive the fungus and initiate defense mechanisms. We reasoned that intracellular accumulation of $\beta$-cryptogein in the plant before attack could provide the pro-

Corresponding author: D. Tepfer; E-mail: tepfer@versailles.inra.fr tein signal not produced by $P$. parasitica var. nicotianae. We thus expressed both $\beta$-cryptogein and the lysine to valine mutant $(\mathrm{K} 13 \mathrm{~V})$ in tobacco under the control of the 35S CaMV viral promoter. Plant transformation was as described (Horsch et al. 1988), with pBin19 (Bevan 1984) as the bacterial vector and the doubled haploid XHFD8 as the plant recipient. Gene expression was controlled by the $35 \mathrm{~S}$ CaMV promoter and the nos terminator. Polymerase chain reaction (PCR) primers for the $\beta$-cryptogein gene were 5'-TACTCTATGTTGACTGCC AAGG and 5'-AGAGAATCCGTTAGCG, and Western blotting (immunoblotting) was performed as previously detailed (O’Donohue et al. 1995).

Putative transformed plants $\left(\mathrm{T}_{0}\right.$ generation) were selfed, and their progeny were tested for homozygosity of the foreign DNA by sowing their seeds $\left(\mathrm{T}_{2}\right.$ generation) on medium containing kanamycin. Since the kanamycin resistance marker was linked to the $\beta$-cryptogein gene in the transferred DNA, homozygotes were recognized by uniform resistance to the antibiotic in seeds produced by selfing or crossing with the wild type. Hemizygotes were produced by crossing homozygotes with the wild type. Aside from kanamycin resistance, evidence for transformation was obtained by PCR amplification of a fragment from the $\beta$ cryptogein gene (not shown). Cryptogein was detected (Fig. 1) by Western blotting after fractionation of total protein by high-pressure liquid chromatography (O'Donohue et al. 1995). The growth of controls and transformants in the

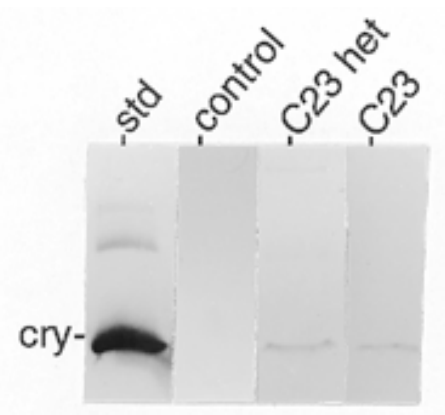

Fig. 1. Western blot (immunoblot) showing cryptogein protein in transformed line 23 hetero- and hemizygotes. The protein was also detected in the other lines (not shown), but not in the nontransformed controls. 
greenhouse, in the growth chamber, in soil, and in aeroponic culture was measured. We found no adverse effects of the foreign gene on root and shoot system growth and development, nor on seed production (not shown).

Pathogenicity tests were conducted with $P$. parasitica var. nicotianae, with plants of various ages and both stem and root inoculation methods. Phytophthora strains were cultured on malt-agar medium (11 g per liter). For stem inoculations with strain INRA A183, agar plugs containing mycelium were cut in a ring, following a line of constant fungal density around the petri dish, from 5- to 7-day-old cultures initiated by inoculation in the center of the dish. Plants ( 8 weeks old) were inoculated with agar plugs after decapitation just below the third or fourth leaf below the shoot apex, and the stem and

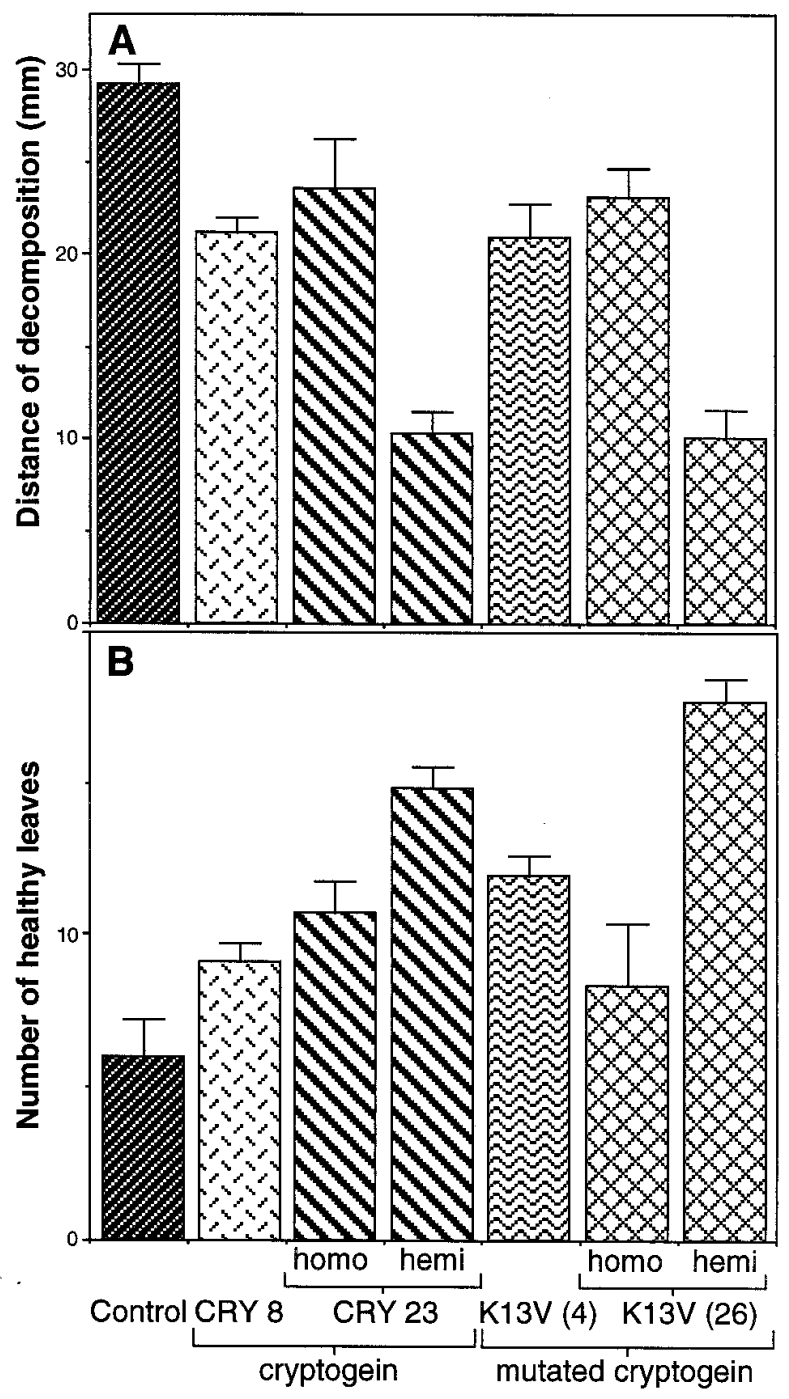

Fig. 2. Quantification of the reaction of transformed and control plants to two types of fungal inoculation. A, Degree of tissue destruction after decapitation and inoculation with mycelium. Measurements were made 14 days after inoculation of 8-week-old sibling plants at the 4- to 5-leaf stage. Results are representative of a series of three experiments; $n=10$ for each category in each repetition. Error bars: standard error of the mean. No necrosis occurred in uninoculated controls. B, Maintenance of healthy leaves (per plant) after zoospore inoculation. Data were collected 1 month after inoculation. Results are representative of three experiments; $n=10$. Error bars: standard error of the mean. plug were protected against drying by a food wrap, polyvinylchloride film. Experiments were conducted at least five times under varying conditions of inoculum size and temperature. Representative results are shown. In experiments carried out at $20^{\circ} \mathrm{C}$ fungal infectivity was poor, resulting in resistance in the controls. At $30^{\circ} \mathrm{C}$ the fungus was extremely aggressive, overcoming the resistance associated with transformation. At $25^{\circ} \mathrm{C}$ destruction of stem tissue 2 weeks after inoculation was reduced in the four homozygous lines carrying either the native $\beta$-cryptogein gene or the mutant, and it was further reduced in two hemizygous lines derived from the homozygotes by crossing with the wild type (Fig. 2A).

The ability of the plant to produce healthy lateral branches after decapitation and inoculation with mycelium was assessed 1 month after inoculation of decapitated stems. In stem inoculations (Fig. 3) the native $\beta$-cryptogein gene conferred better resistance than the mutated form, and there was variability among lines, as expected in transformation experiments, where the site of insertion of the foreign DNA can be a major factor in the degree of penetration of the transformed phenotype.

In an effort to vary the form of fungal infection, young plants were inoculated with 70,000 zoospores, applied to the soil in $5 \mathrm{ml}$ of water; they were produced with strain P329, as described (Keller et al. 1996). Zoospores were applied through the soil in $5 \mathrm{ml}$ of water. Inoculated plants were maintained at $25^{\circ} \mathrm{C}$ in growth chambers with a 16-h photoperiod. In all cases, fungal attack on the root system led to root rot and reduced plant growth, sometimes resulting in death through systemic infection. Reduction in growth and the production of healthy leaves was, however, less severe in the transformed lines, and this difference was more pronounced in the hemizygotes (Fig. 2B), which managed to flower in line 23 (not shown). Flowering and seed production, like the growth of lateral branches, allow plants to survive pathogen attack through sexual propagation. One of the transformed lines carrying the mutated gene in homozygous form, K13V (line 4), was clearly more resistant to zoospore infection than the controls, but a second line transformed by the same gene, K13V (line 26), was only resistant when the foreign gene was in the hemizygous state (Fig. 2B).

$\beta$-cryptogein is thought to interact with the cell membrane (Wendehenne et al. 1995), setting off a signal transduction cascade that leads to a generalized defense response or systemic acquired resistance (SAR), including the induction of pathogenesis-related (PR) proteins (Wendehenne et al. 1995; Keller et al. 1996; Perez et al. 1997). Infection of both control and $\beta$-cryptogein transformants with $P$. parasitica var. nicotianae caused the expected appearance of PR proteins $2 \mathrm{a}, 3 \mathrm{~b}$, and $5 \mathrm{~b}$ (not shown), which were not induced in uninoculated controls. In the absence of infection, both control and transformed plants produced only a basal level of salicylic acid (ca. $30 \mathrm{ng}$ per $\mathrm{g}$ of fresh weight of leaf). Thus, the transformants were not in a state of constitutive SAR.

Although the accumulation of $\beta$-cryptogein within the cell causes no detectable abnormalities in growth and defense responses, the protein might be liberated upon cell death due to fungal infection. Strains of $P$. parasitica that produce elicitins are generally avirulent in tobacco, while $P$. parasitica var. nicotianae does not secrete elicitins and is pathogenic. Thus, the expression of the $\beta$-cryptogein gene in tobacco could provide the elicitin that $P$. parasitica does not 
make, counteracting the pathogen's ability to circumvent the plant's alarm system. If this is the case, elicitin genes might protect other species against Phytophthora or might be used to combat other invasive pathogens. Given the possibility that plants may acquire foreign genes from soil microor- ganisms, such as Agrobacterium (see discussion in Tepfer 1989), it seems reasonable to speculate that on an evolutionary time scale natural transformation could provide plants with genes encoding pathogen protein elicitors, such as $\beta$ cryptogein.
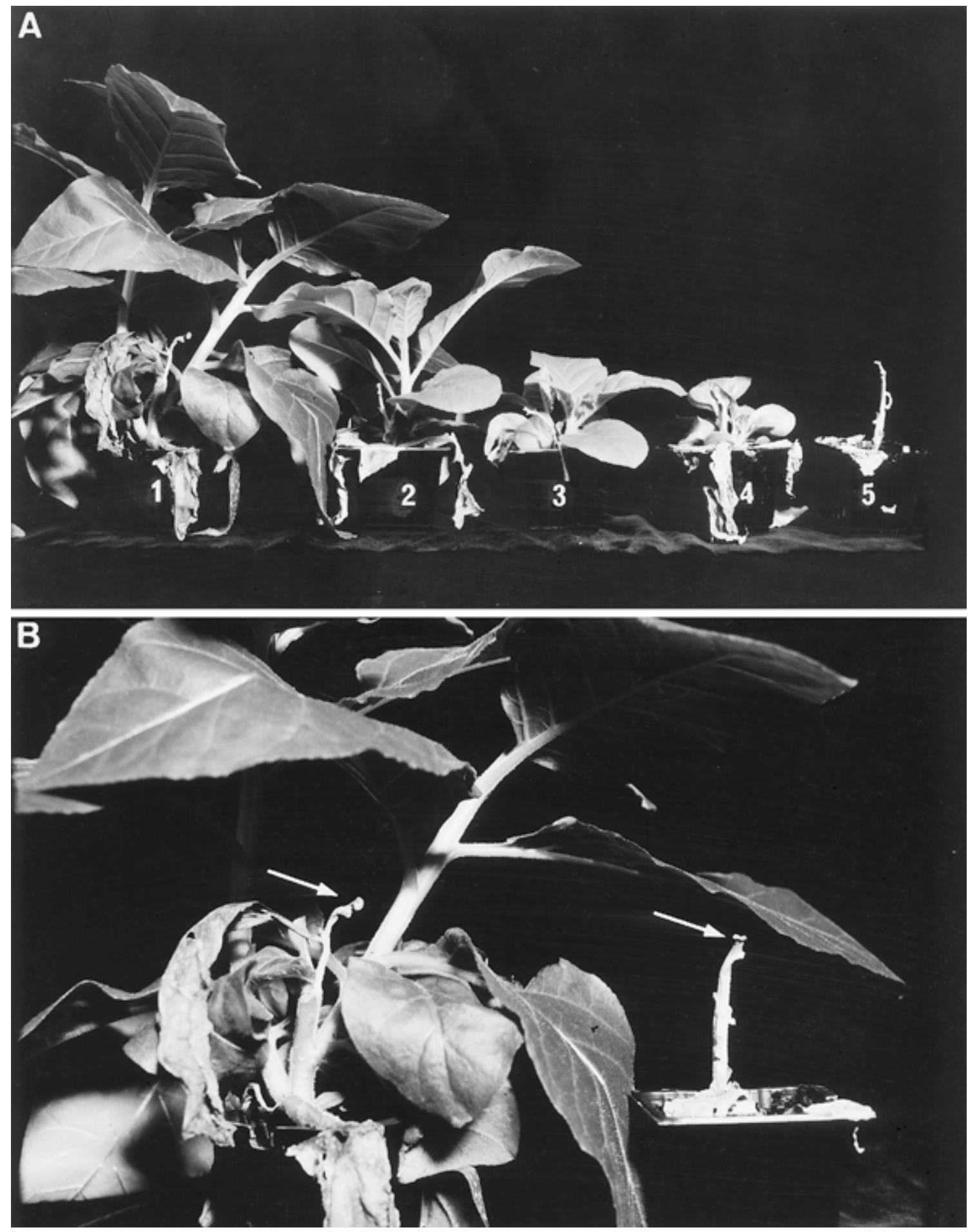

Fig. 3. Illustration of recovery through the growth of lateral branches after decapitation and inoculation with mycelium. Representative plants shown; $n$ $=10$. A, Growth 1 month after inoculation. From left to right: plant 1, cryptogein gene in homozygous line 23; plant 2, same gene in homozygous line 8; plant 3, k to v mutation at position 13 (line 26); plant 4, same mutant (line 4); plant 5, nontransformed control. B, Close view of plants on far left and far right from (A), showing the site of inoculation (arrows) and extent of tissue decomposition. Infection destroyed the control plants, but was arrested in transformants in the internode below the first leaf under the site of inoculation, allowing the growth of axillary buds in the remainder of the stem. 


\section{ACKNOWLEDGMENTS}

We are indebted to B. Fritig and S. Kauffmann (IBMP, CNRS, Strasbourg, France) for the PR protein antisera and P. Bonnet (INRA, Antibes) for $P$. parasitica var. nicotianae strains and the method for producing zoospores.

\section{LITERATURE CITED}

Bevan, M. 1984. Binary Agrobacterium vectors for plant transformation. Nucleic Acids Res. 12:8711-8721.

Boissy, G., de La Fortelle, E., Kahn, R., Huet, J.-C., Bricogne, G., Pernollet, J.-C., and Brunie, S. 1996. Crystal structure of a fungal elicitor secreted by Phytophthora crytogea, a member of a novel class of plant necrotic proteins. Structure 4:1429-1439.

Csinos, A., and Hendrix, J. 1977. Toxin produced by Phytophthora cryptogea. Can J. Bot. 55:1156-1162.

Csinos, A., and Hendrix, J. 1978. Phytophthora species producing toxin active on tobacco. Soil Biol. Biochem. 10:47-51.

Horsch, R., Fry, J., Hoffmann, N., Neidermeyer, J., Rogers, S. G., and Fraley, R. 1988. Leaf disc transformation. Page A5:1-9 in: Plant Molecular Biology Manual. S. Gelvin, R. Schilperoort, and D.-P. Verma, eds. Kluwer Academic Publishers, Dordrecht, The Netherlands.

Kamoun, S., Young, M., Glascock, C. B., and Tyler, B. M. 1993. Extracellular protein elicitors from Phytophthora: Host-specificity and induction of resistance to bacterial and fungal phytopathogens. Mol. Plant-Microbe Interact. 6:15-25.

Keller, H., Blein, J.-P., Bonnet, P., and Ricci, P. 1996. Physiological and molecular characteristics of elicitin-induced systemic acquired resisstance in tobacco. Plant Physiol. 110:365-376.

Nespoulous, C., Huet, J.-C., and Pernollet, J.-C. 1992. Structurefunction relationships of $\alpha$ and $\beta$ elicitins, signal proteins involved in the plant-Phytophthora interaction. Planta 186:551-557.

O’Donohue, M., Gousseau, H., Huet, J.-C., Tepfer, D., and Pernollet, J.C. 1995. Chemical synthesis, expression and mutagenesis of a gene encoding $\beta$ cryptogein, an elicitin produced by Phytophthora cryptogea. Plant Mol. Biol. 27:577-586.

Perez, V., Huet, J.-C., Nespoulous, C., and Pernollet, J.-C. 1997. Mapping the elicitor and necrotic sites of Phytophthora elicitins with synthetic peptides and reporter genes controlled by tobacco defense gene promoters. Mol. Plant-Microbe Interact. 10:750-760.

Pernollet, J. C., Sallantin, M., Sallé-Tourne, M., and Huet, J.-C. 1993. Elicitins isoforms from seven Phytophthora species: Comparison of their physico-chemical properties and toxicity to tobacco and other plant species. Physiol. Mol. Plant Pathol. 42:53-67.

Ricci, P., Bonnnet, P., Huet, J. C., Sallantin, M., Beauvais-Cante, F., Bruneteau, M., Billard, V., Michel, G., and Pernollet, J. C. 1989. Structure and activity of proteins from pathogenic fungi Phytophthora eliciting necrosis and acquired resistance in tobacco. Eur. J. Biochem. 183:555-563.

Tepfer, D. 1989. Ri T-DNA from Agrobacterium rhizogenes: a source of genes having applications in rhizosphere biology and plant development, ecology and evolution. Page 294-342 in: Plant-Microbe Interactions. T. Kosuge and E. Nester, eds. McGraw Hill, New York.

Wendehenne, D., Binet, M.-N., Blein, J.-P., Ricci, P., and Pugin, A. 1995. Evidence for specific, high-affinity binding sites for a proteinaceous elicitor in tobaccco plasma membrane. FEBS Lett. 374:203-207. 